\title{
Felszín alatti beáramlás hatása a Tisza vízminőségére a Közép-Tisza vidékén
}

\section{The Effect of the Groundwater Inflow on the Water Quality of the Tisza in the Middle Tisza District}

\begin{abstract}
A Tisza Magyarország egyik legjelentősebb folyójának tekinthető. Az elmúlt évtizedek során a rendkivüliárhullámok mellett a vizhiányos időszakok is egyre nagyobb kihivások eléállitják a vizügyi szakmát. A klímaváltozás ezt a folyamatot egyre inkább erősíteni fogja. A rendkívüli árhullámok, illetve aszályos időszakok valószínüsége növekvő tendenciát mutat. A folyó Szolnok térségének ivóvizellátását is biztositja, ami alacsony mederteltség esetében veszélybe kerülhet. A folyó apadása során, amikor magasabban van a talajvíz szintje a Tiszához viszonyítva, érvényesül a folyó leszívó, megcsapoló hatása. A talajvízböl ebben az esetben esély van különböző szennyezőanyagok folyóba áramlására.

Jelen írás célja, hogy bemutassa, a Tisza folyó tartósan alacsony mederteltsége esetén a felszín alatti beáramló vizek milyen mértékben jelenthetnek veszélyforrást a folyó vízminőségére. Bemutatom a mintavételezési eljárásokat, illetve a vizsgálati eredményeket is.
\end{abstract}

Kulcsszavak: vízminőség, vízhiány, talajvíz, felszíni víz, mintavétel

The Tisza is considered to be one of the most significant rivers in Hungary. In addition to extreme floods in recent decades, periods of water scarcity are challenging the water industry. Climate change will also strengthen this process. The likelihood of extreme floods and droughts is increasing. The river also provides drinking water supply to the Szolnok area, which could be endangered during low-water periods. During the recession of the river, when the groundwater level is higher than the water level of the Tisza, the draining effect of the river prevails. In this case, there is a chance for groundwater to release different pollutants into the river.

Közép-Tisza-vidéki Vízügyi Igazgatóság, kiemelt müszaki referens, e-mail: vizi.david.bela@kotivizig.hu, ORCID: https://orcid.org/0000-0003-2224-9424 
The aim of this paper is to show that the groundwater inflows may pose a threat to the quality of the river during low water periods. Sampling procedures and the water quality test results are also presented.

Keywords: water quality, water scarcity, groundwater, surface water, sampling

\section{Bevezetés}

A Tisza-vízgyűjtő az Európai vízgyűjtők között különlegesnek tekinthető. Bizonyos hidrometeorológiai helyzetekben a rendkívüli árhullámok kialakulására komoly az esély. A 2000-es évek elején ez különösen igaz volt, hiszen egymást követték a rekordvízállásokat produkáló árhullámok a Tisza magyarországi szakaszán. ${ }^{2}$ Ezzel egy időben, az elmúlt évtizedekben a vízhiányos időszakok is egyre nagyobb kihívások elé állítják a vízügyi szakmát. Az aszályos periódusok különösen a Tisza-vízgyűjtő síkvidéki területeit érinti. E szélsőséges hidrometeorológiai szituációk kialakulásában komoly szerepet játszik a klímaváltozás hatása. ${ }^{3}$

Az elmúlt időszak európai szintű aszályjelenségeinek területi és időbeli eloszlását vizsgálva kijelenthető, hogy hazánkat valamennyi nagy európai aszály sújtotta. Magyarország területének körülbelül 90\%-án magas az aszály kialakulásának a kockázata, a leginkább veszélyeztetett az Alföld térsége. ${ }^{4} \mathrm{Az}$ aszályjelenségek károsító hatását lehetőség van csökkenteni a hatékonyabb vízgazdálkodási, illetve öntözési technikák alkalmazásával. Különösen fontos e metódusok feltárása, mivel a jövőben a több évig tartó, száraz időjárási jelenségek előfordulási gyakorisága egyre növekvő tendenciát mutat. ${ }^{5}$ Hazánkban átlagosan 10 évből 3-4 aszályosnak tekinthető. Különösen a gördülőaszály-jelenségek lettek kritikusak, amikor az egymás utáni aszályos évek többszörössé fokozzák az előző évek káros hatásait. ${ }^{6} \mathrm{Az}$ átlagos éves vízhiány hazánkban a vízmérlegszámítások alapján 200-250 mm körül mozog. A szélsőségesen száraz hidrometeorológiai jelenségeknek köszönhetően az öntözésre felhasznált vizek mennyisége is növekedni fog. ${ }^{7} \mathrm{Ha}$ zánkban a megfelelő mennyiségű víz, megfelelő időben történő rendelkezésre állásáért a Vízügyi Igazgatóságok felelnek. A vízgazdálkodás rövid, illetve hosszú távú feladatait megfogalmazó Nemzeti Vízstratégia kiemelt figyelmet fordít arra, hogy a vízválság hazánkat elkerülje, illetve hogy kellő biztonságban legyünk a fenyegető szélsőséges hidrometeorológiai jelenségektől. ${ }^{8}$

A vizsgálat fő célja az volt, hogy a Tisza folyó tartósan alacsony mederteltsége esetén a felszín alatti beáramló vizek milyen mértékben jelenthetnek veszélyforrást a folyó vízminőségére.

Szlávik Lajos: A Duna és a Tisza szorításában. Budapest, Közdok, 2006.

3 Bernhard Lehner et alii: Estimating the Impact of Global Change on Flood and Drought Risks in Europe: A Continental, Integrated Analysis. Climatic Change, 75. (2006), 3. 273-299.

4 Tamás János: Kihívások az aszálykutatás területén. Hidrológiai Közlöny, 96. (2016), 2. 13-20.

5 Szalai Sándor: Drought Tendencies in Hungary and Its Impacts on the Agricultural Production. Cereal Research Communications, 37. (2009), 501-504.

6 Pálfai Imre: Aszályok a Tisza-völgyben. In Fejér László - Kaján Imre (szerk.): Mérlegen a Tisza-szabályozás. Budapest, Magyar Hidrológiai Társaság - Országos Vízügyi Főigazgatóság, 1992. 33-40.

7 Somlyódy László: Magyarország vízgazdálkodása: helyzetkép és stratégiaifeladatok. Budapest, Magyar Tudományos Akadémia, 2011. Elérhető:

8 Nemzeti Vízstratégia. Budapest, Országos Vízügyi Főigazgatóság, 2017. Elérhető: www.vizugy.hu/vizstrategia/documents/997966DE-9F6F-4624-91C5-3336153778D9/Nemzeti-Vizstrategia.pdf (A letöltés dátuma: 2019. 04. 02.) 
Ez a miatt is fontos feladatnak tekinthető, hiszen Szolnok térségének ivóvízellátása a Tiszán található felszíni víztisztító mű segítségével történik. Tartósan kisvizes időszak folyamán bizonyos komponensek esetében nehezen lehet tartható a 201/2001. (X. 25.) kormányrendeletben meghatározott határérték. ${ }^{9}$

Ehhez elsősorban meg kell határozni a hozzáfolyás mennyiségét, valamint vizsgálni annak minőségét. Maga a hozzáfolyás jelensége a Tiszai mederteltségtől függően a vízszintváltozások mértékétől az apadás ütemétől, a tartósságtól jelentős eltéréseket mutathat. Ennek legalább nagyságrendileg helyes meghatározásához rendkívül sokváltozós nagy vizsgált területre kiterjedő bonyolult számítási eljárás vagy még inkább hidrodinamikai modell felépítése és futtatása lenne alkalmas. Jelen dokumentum a különböző pontokon vett mintavételezési eljárást és a vizsgálati eredmények kiértékelését mutatja be.

\section{A Tisza folyó hidrológiai jellemzése}

A Tisza a Duna leghosszabb, legnagyobb vízgyűjtő területtel rendelkező mellékfolyója, Közép-Európa egyik legjelentősebb folyója. Az Ukrajnában lévő Máramarosi-havasokban eredő Fekete- és Fehér-Tisza összefolyásából keletkezik. Teljes vízgyüjtő területe 157 ezer km². A Tisza leghosszabb és végig szabályozott szakasza Magyarország területén található. Hazánk területének a fele tartozik a Tisza vízgyüjtőjéhez, $46737 \mathrm{~km}^{2}{ }^{2}{ }^{10}$

A Tisza forrásvidékének nagy esésű hegyvidéki szakaszain mederről még nemigen lehet beszélni. Az Alföldre kiért folyó már mélyen beágyazott mederben fut, esése fokozatosan csökken. Az alsó szakasz irányába a Bodrog torkolatától mederanyagként megjelenik az iszap és az agyag. Az Alsó-Tisza mederanyagára ugyancsak a rendkívül kis szemcseátmérő a jellemző. A folyó e szakaszán a mederesés $4 \mathrm{~cm} / \mathrm{km}$-re csökken. ${ }^{11}$

A síksági folyók jellegzetessége a kanyargósság. A meanderezés jól megfigyelhető a Tisza felső szakaszán, ahol a Borsa torkolatáig az eredeti állapotok láthatóak. A folyó alsóbb szakaszán a folyó mederformáló képessége következtében a szabályozások óta is hozott létre kanyarulatokat. ${ }^{12}$ Az Alföldön a folyó középvízi medrének szélessége átlagosan 100 m körüli. Egyes szelvényekben azonban ettől az értéktől jelentősen eltérhet. Szolnoknál például csupán 95 m-es a szükület. Az árvízvédelmi töltések közötti hullámtéri területek átlagosan 1400-1800 $m$ szélesek, azonban számos helyen az átlag felét sem érik el.

A Tisza magyarországi mellékfolyói - a Zagyva kivételével - mind külföldön erednek, és a folyó vízgyűjtő területének is csupán 30\%-a tartozik hazánkhoz. A folyami lefolyásnak ennél sokkal kisebb hányada származik a hazai vízgyűjtőkröl, a folyók vízjárását éppen ezért döntően nem a hazai, hanem más országok területén keletkező vizek alakítják, befolyásolják.

\footnotetext{
201/2001. (X. 25.) Korm. rendelet az ivóvíz minőségi követelményeiről és az ellenőrzés rendjéről.

Lászlóffy Woldemár: A Tisza. Budapest, Akadémiai Kiadó, 1984.

Szlávik Lajos: Vizkárelhárítási kézikönyv. Budapest, Országos Vízügyi Főigazgatóság, 2016.

12 Kovács Sándor: Kisköre, déli országhatár közötti Tisza szakasz lefolyásviszonyainak jellemzése. Kézirat. ATIKÖVIZIG - KÖTIKÖVIZIG, 2007. 1-43.
} 
A magyarországi folyókra az árvizek előfordulása mellett az éven belüli változékonyság a jellemző. Kisvizek túlnyomórészt az őszi és a téli időszakban állnak elő. A vízhozamok és a vízjáték széles határok között ingadozik (1. táblázat).

1. táblázat. A Tisza folyó hidrológiai jellemzői

\begin{tabular}{|c|c|c|c|c|}
\hline \multirow{2}{*}{ Folyó } & \multirow{2}{*}{ Vízmérce } & \multirow{2}{*}{ Vizjáték $(\mathbf{c m})$} & \multicolumn{2}{|c|}{ Vízhozam $\left(\mathbf{m}^{\mathbf{3}} / \mathbf{s}\right)$} \\
\cline { 3 - 5 } & & & Észlelt minimum & Észlelt maximum \\
\hline Tisza & Vásárosnamény & 1178 & 47 & $3930(1970)$. \\
\hline Tisza & Szolnok & 1320 & 55 & $3320(1895)$. \\
\hline Tisza & Szeged & 1259 & 95 & $3820(1970)$. \\
\hline
\end{tabular}

Forrás: KÖTIVIZIG

A Közép-Tisza vidékén vízhiányos időszakról akkor beszélhetünk, amikor a folyó vízhozama a Kiskörei tározó felső, tiszabábolnai szelvényében $105 \mathrm{~m}^{3} / \mathrm{s}$ alá csökken. A Kisköre alatti alvízi szakaszon ekkor is biztosítani kell az élővilág számára elengedhetetlen $60 \mathrm{~m} 3 / \mathrm{s}$ minimális vízhozamot. A 2003. évi rendkívül aszályos időszak során Szolnoknál a vízállás negatív rekordot döntött (LKV $=-279 \mathrm{~cm}$ ), a vízhozammérések tanúsága szerint ekkor $55 \mathrm{~m}^{3} / \mathrm{s}$ közeli vízhozam tartozott, amelynél a felszíni vízkivételi mủ még éppen üzemképes maradt. A vízgazdálkodásról szóló 1995. évi LVII. törvény alapján az ivóvíz biztosítása a legelső szempont, ezért az utóbbit fogadták el mértékadó állapotnak. ${ }^{13}$

Az Alföld jelentős részét a Tisza-Körös-völgyi Együttműködő Vízgazdálkodási Rendszeren (röviden TIKEVIR) keresztül látják el a Tiszából származó szükséges vízkészlettel. A TIKEVIR jelenlegi rendszerének fő gerincét a Keleti-, Nyugati- Jászsági- és a Nagykunsági-főcsatornák alkotják. ${ }^{14} \mathrm{~A}$ meglévő és a felhasznált vízhozamok arányát jól szemlélteti, hogy a Tisza kisvízi 100-120 m³/s-os vízhozamából a Keleti-föcsatornába 24-26 m³/s-ot, a Nagykunsági-főcsatornába 26-30 m³/s-ot, a Tiszafüredi-föcsatornába 1-3 m³/s-ot, míg a Jászsági-főcsatornába 2-4 m³/s-ot (összesen mintegy 53-63 m³/s) vezetnek ki. A kisebb csatornákkal együtt behálózza az Alföldet, biztosítva a térség vízpótlását. Nélküle aszályos, száraz nyári időben ma már kiszáradna a Körös-völgy és a Tisza-völgy jelentős része. A TIKEVIR elsősorban az ökológiai vízpótlást, öntözést, halastavak vízellátását és a többletvíz elvezetését szolgálja. Szélsőségesen vízhiányos időszakban azonban a Tisza minimális vízhozamának fenntartása érdekében szükségessé válhat a térség vízpótlásának a korlátozása. Ebben az esetben a csatornákba átvezetett vízmennyiséget csökkentik.

A 21. század rendkívüli árhullámai mellett egyre gyakrabban alakultak ki tartósan vízhiányos időszakok a Tisza mentén. Az elmúlt két évtized alatt kiemelendő a 2003-as, a 2012-es és a 2015-ös év, amelyek során minden esetben rendkívüli intézkedések bevezetésére került sor. A Tisza Kisköre alatti folyószakaszán a minimálisan tartandó 60 m³/s-ot a Kiskörei tározóban

1995. évi LVII. törvény a vízgazdálkodásról.

14 Virágné Kőházi-Kiss Edit - Fejes Lőrinc: A Tisza-tó szerepe az aszály mérséklésében. Budapest, XXXIV. Országos Vándorgyủlés konferenciakiadványa, 2016. Elérhető: www.hidrologia.hu/vandorgyules/34/dolgozatok/ word/0329_viragne_kohazi_kiss_edit.pdf (A letöltés dátuma: 2019. 10. 12.) 
visszatartott többletvíztömeg felhasználásával, valamint a TIKEVIR-be kevesebb vízmennyiség átvezetésével biztosították.

A folyó apadása során, amikor magasabban van a talajvíz szintje a Tiszához viszonyítva, érvényesül a folyó leszívó, megcsapoló hatása. Ez a jelenség a folyó parti sávjában mutatkozik meg a legerőteljesebben (1. ábra). Tartósan kisvizes időszakban lehetőség van e hozzáfolyások felmérésére.

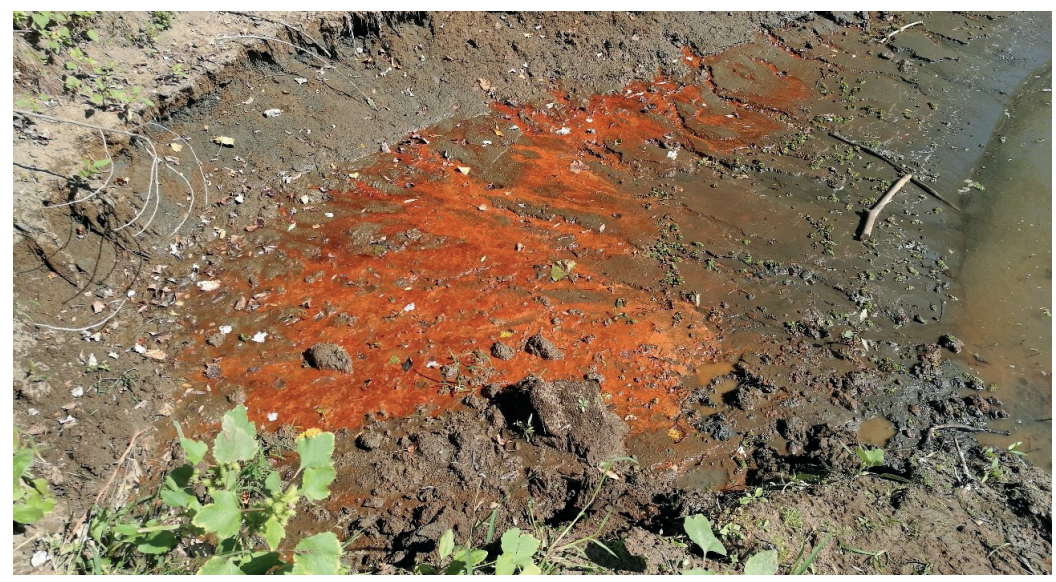

1. ábra. Felszín alatti hozzáfolyás a Tisza 311 fkm-nél jelentős vas- és mangánkicsapódással

Forrás: a szerző felvétele

\section{Mintavételi eljárás ismertetése}

A tartósan alacsony mederteltségek esetén, pontszerüen, illetve hosszabb-rövidebb szakaszokon, ahol a vízzáró réteg a rézsűben vagy a mederfenéken kimetsződik és a vízállás ez alá a szint alá csökken, a felszín alatti vizek lepelszerü beáramlása szabad szemmel megfigyelhető. Ezeken a helyeken volt lehetőség a beáramló vizek lokális mennyiségének becslésére, illetve a vízkémiai vizsgálatokhoz szükséges minták begyüjtésére.

A mintavételre két évben is sor került a folyó ugyanazon folyószakaszán. 2016. szeptember 29-én, a szolnoki vízmércén mért -227 cm-es vízállásnál a Tisza bal part 323-as fkm-nél lévő partszakasz szivárgó vizéből (2-es számú mintavételi pont). 2019. szeptember 20-án három ponton is történt mintavételezés a Tisza folyó bal partján: a 326 fkm-nél (1-es számú mintavételi pont), a 320-as fkm-nél (3-as számú mintavételi pont) és a 311-es fkm-nél (4-es számú mintavételi pont). A mintavételek időszakában a szolnoki vízmércén $-256 \mathrm{~cm}$ volt a vízállás.

A 2. ábra ismerteti a mintavételi helyeket, folyásiránynak megfelelő sorrendben. A 2019-es év folyamán Szolnok és Csongrád között regisztrálva lettek a part mentén látható hozzáfolyások nyomai is (térképen narancssárgával jelölve). A szeptemberi felméréskor a Tisza már közel egy hónapja ebben a vízállástartományban volt, így a legtöbb helyen már hozzáfolyás nem történt. A következő évek felmérései során már a folyó apadása alatt szükséges lenne a terület bejárására, illetve a mintavételezés megkezdésére. 


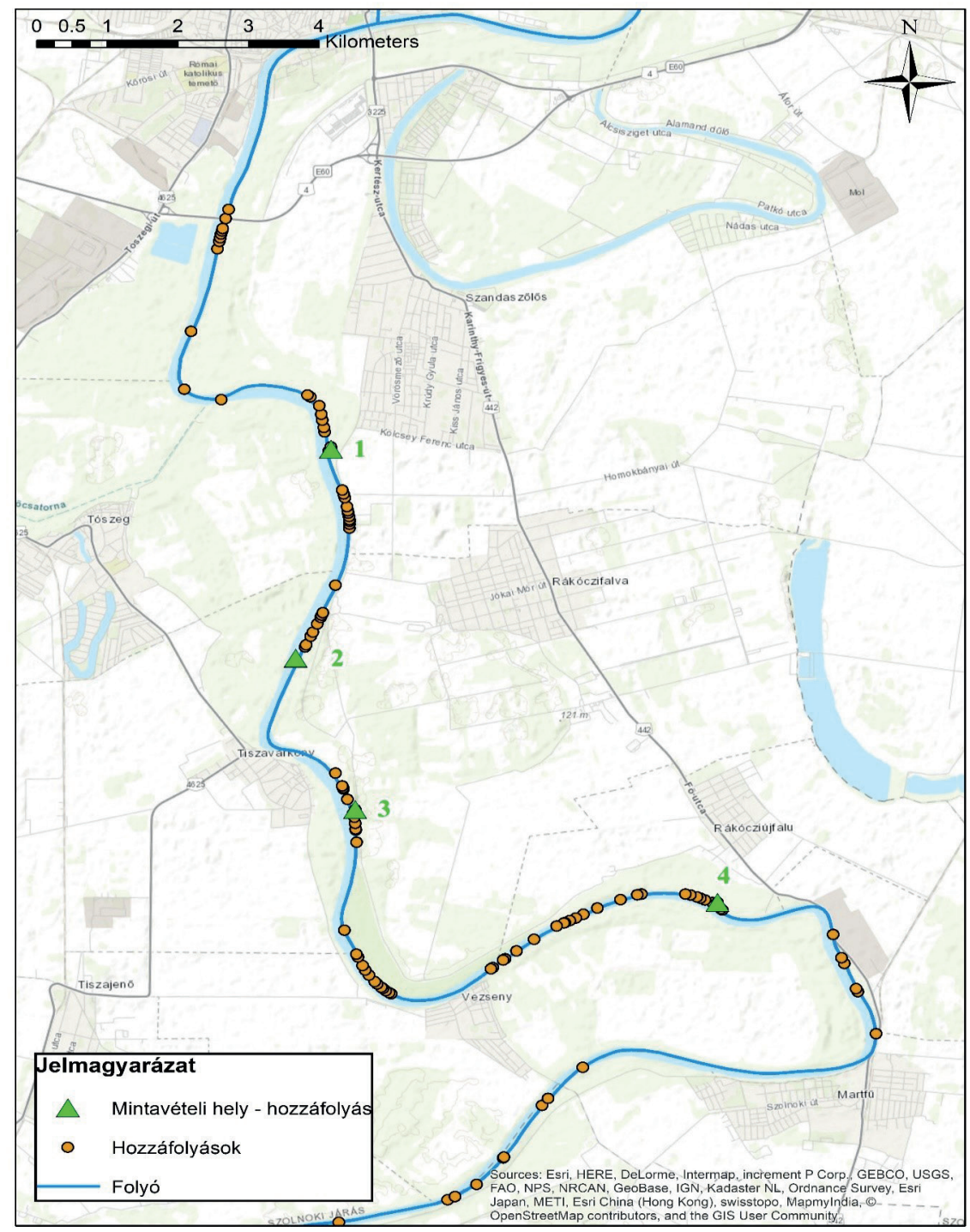

2. ábra. Mintavételi helyek a Tisza Szolnok és Martfü közötti szakaszán

Forrás: a szerző szerkesztése

A 326 és 311 fkm közötti szakaszon több helyen is a korábban ismertetett jellegzetes, partról is jól megközelíthető, felszíni beszivárgás volt tapasztalható mindkét évben. A vízminta vételéhez az alábbi fényképen bemutatott módszert alkalmaztuk (3. ábra). A mederrézsűben tapasztalt szivárgás helyén a rézsűbe közel $\sim 8$ m hosszú gyűjtőárkot készítettünk, amelyet egy gyűjtő- 
zsompba vezettünk. A gyüjtőzsompból a folyó felé túlfolyót ágaztattunk. A gyűjtőárkot, valamint a zsompot a mérést megelőző napon készítettük, amelyben már aznap szemmel láthatóan megindult az összegyülekezés. A mennyiségi mérés pontossága, valamint a vizsgálandó minták „zavartalansága” érdekében a mérést és mintavételezést csak az azt követő napon végeztük el. Ekkor szemmel láthatóan kiülepedett tiszta víz volt a gyűjtőzsompban és a beömlő csövön, valamint a túlfolyón keresztül egyenletes beállt áramlás volt tapasztalható. Így lehetőség volt a szükséges vízminta begyüjtésére, valamint a vizsgált szakaszon lokálisan befolyó mennyiség köbözéssel történő becslésére. Ez azonban kizárólag a gyűjtőárokba beszivárgó víz mennyiségének a becslését tette lehetővé.

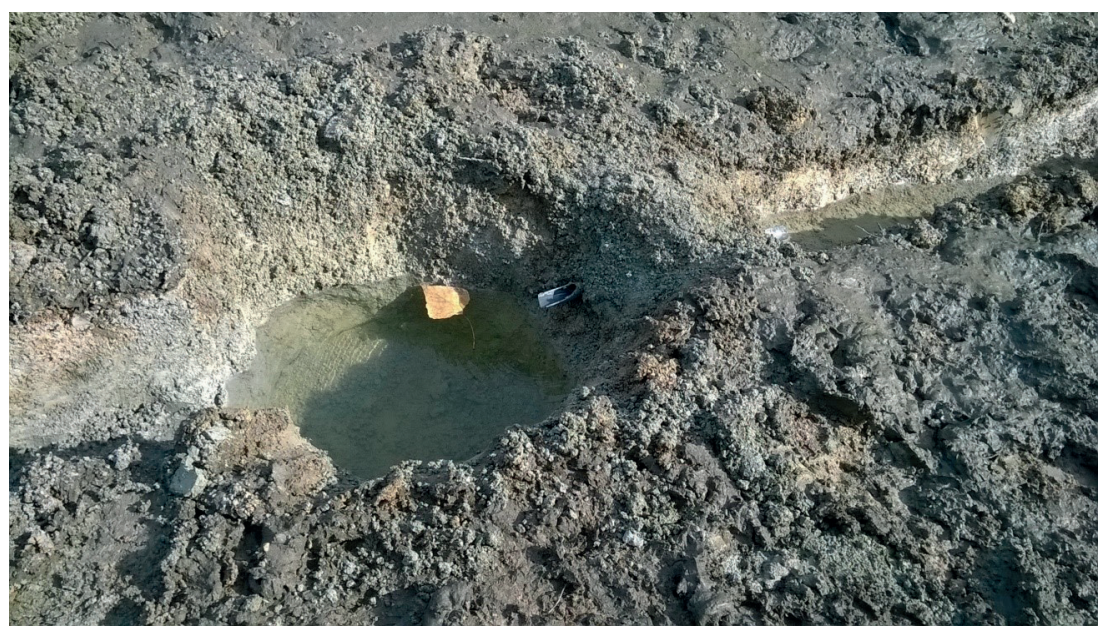

3. ábra. Gyüjtőzsomp kialakítása

Forrás: a szerző felvétele

Ebből egzakt módon nem generálható az egyes szakaszokon tapasztalható hozzáfolyás mennyisége. A felszínen, azaz a mederrézsűn megjelenő hozzáfolyások kiterjedése és intenzitása jelentős eltéréseket mutatnak, valamint ezen túlmenően a vízzáró réteg felszínének eltérő domborzata miatt számos szemmel nem látható víz alatti hozzáfolyás is feltételezhető.

\section{Vízkémiai vizsgálati eredmények}

A vizsgálat célja az volt, hogy a szivárgóvíz vizsgált paramétereinek koncentrációja mennyiben tér el a Tisza vízminőségétől.

A 2. táblázat eredményeiből jól látható, hogy a szivárgóvizek komponenseinek koncentrációja igen nagy változékonyságot mutat. A Tisza 2016-os és 2019-es mintatételeinek az eredményei között azonban egyik paraméter esetében sem tapasztalható jelentős eltérés. 
2. táblázat. A Tisza és a szivárgóvizek mintavételének vizsgálati eredményei (vastaggal jelölve a jelentős eltérések)

\begin{tabular}{|c|c|c|c|c|c|c|}
\hline Komponensek & Tisza 2016 & Tisza 2019 & 1-es helyszín & 2-es helyszín & 3-as helyszín & 4-es helyszín \\
\hline$p H$ & 8,05 & 7,79 & 6,74 & 7,91 & 7,31 & 7,25 \\
\hline $\begin{array}{l}\text { Fajlagos elektromos vezetö- } \\
\text { képesség }(\mu \mathrm{S} / \mathrm{cm})\end{array}$ & 490 & 529 & 3220 & 1064 & 772 & 1378 \\
\hline Fenolft. lúgosság (mmol/l) & - & - & - & - & - & - \\
\hline $\begin{array}{l}\text { Metilnarancs lúgosság } \\
(\mathrm{mmol} / \mathrm{l})\end{array}$ & 3,0 & 2,7 & 12,2 & 9,4 & 7,2 & 6,5 \\
\hline Összes keménység (mg/l) & 102 & 90 & 1227 & 283 & 238 & 422 \\
\hline $\mathrm{Ca}^{2+}(m g / l)$ & 55 & 48 & 654 & 147 & 134 & 235 \\
\hline$M g^{2+}(m g / l)$ & 11 & 9,7 & 133 & 34 & 21 & 40 \\
\hline $\mathrm{Na}^{+}(m g / l)$ & 36 & 38 & 121 & 83 & 21 & 45 \\
\hline$K^{+}(m g / l)$ & 3,7 & 3,7 & 3,4 & 3,2 & 2,6 & 3,6 \\
\hline Összes kation (mgeé/l) & 5,31 & 4,97 & 49,2 & 13,8 & 9,46 & 17,1 \\
\hline Kation tipus & $\mathrm{Ca}$ & $\mathrm{Ca}$ & $\mathrm{Ca}$ & $\mathrm{Ca}$ & $\mathrm{Ca}$ & $\mathrm{Ca}$ \\
\hline $\mathrm{Cl}^{-}(\mathrm{mg} / \mathrm{l})$ & 50 & 54 & 215 & 50 & 30 & 86 \\
\hline $\mathrm{SO}_{4}^{2-}(\mathrm{mg} / \mathrm{l})$ & 59 & 57 & 1461 & 123 & 81 & 444 \\
\hline $\mathrm{HCO}_{3}^{-}(\mathrm{mg} / \mathrm{l})$ & 184 & 167 & 747 & 575 & 439 & 396 \\
\hline $\mathrm{CO}_{3}^{2-}(\mathrm{mg} / \mathrm{l})$ & - & - & - & - & - & - \\
\hline Összes anion (mgeé/l) & 5,65 & 5,46 & 48,7 & 13,4 & 9,73 & 18,16 \\
\hline Anion típus & $\mathrm{HCO}_{3}$ & $\mathrm{HCO}_{3}$ & $\mathrm{HCO}_{3}$ & $\mathrm{HCO}_{3}$ & $\mathrm{HCO}_{3}$ & $\mathrm{HCO}_{3}$ \\
\hline Arzén $(\mu g / l)$ & 2,2 & 1,9 & 38 & 9,5 & 38 & 12 \\
\hline Réz $(\mu g / l)$ & 2,2 & & 3,1 & $<2,0$ & 6 & $<2,0$ \\
\hline Kadmium $(\mu g / l)$ & $<0,1$ & $<2,0$ & $<0,1$ & $<0,1$ & 0,19 & $<0,1$ \\
\hline Króm $(\mu \mathrm{g} / \mathrm{l})$ & $<2,0$ & $<2,0$ & $<2,0$ & $<2,0$ & $<2,0$ & $<2,0$ \\
\hline Higany $(\mu g / l)$ & $<0,04$ & $<0,04$ & $<0,04$ & $<0,04$ & $<0,04$ & $<0,04$ \\
\hline Nikkel $(\mu g / l)$ & 2,2 & $<1,0$ & 4,1 & 2 & 12 & 4,5 \\
\hline $\operatorname{Cink}(\mu g / l)$ & $<10$ & $<10$ & 19 & $<10$ & 42 & $<10$ \\
\hline Ólom $(\mu g / l)$ & $<1,0$ & $<1,0$ & 6,8 & $<1,0$ & 32 & 5,3 \\
\hline $\operatorname{Vas}(\mu g / l)$ & - & $<100$ & 11750 & - & 8310 & 16740 \\
\hline Mangán $(\mu g / l)$ & - & $<20$ & 5061 & - & 9309 & 1582 \\
\hline
\end{tabular}

Forrás: a szerző szerkesztése

A szivárgóvíz elsősorban sótartalomban tért el. A fajlagos elektromos vezetőképessége minden esetben több mint duplája a Tisza sótartalmának, ami felszín alatti víz esetében előfordulhat. A legnagyobb koncentrációt az 1-es mintavételi pontnál határoztunk meg. lontípusváltást azonban semmiképp sem okozhat, hiszen a Tiszához hasonlóan kalcium-hidrogén-karbonátos.

Fontos megemlíteni a szivárgóvizek arzéntartalmát, amely 9,5 és 38 g/l közötti értéket mutat. Tekintettel arra, hogy az ivóvizek arzéntartalmának határértékét $1 \mu g /$ l-re kívánják csökkenteni, jelentős mennyiségű felszín alatti beáramlást feltételezve ez már problémát okozhat, mivel a Tisza kiemelt fontosságú vízbázis. Szolnok város és több környező település ivóvízellátása (közel 40 ezer lakás) a folyóból történik.

A 2019-es mintavételezések esetében a nikkel, cink és az ólom koncentrációja jelentősen magasabb volt a szivárgóvizeknek, amely valamilyen szennyezés jelenlétére utalhat a térségben. A nehézfémszennyezések forrását azonban nehéz egyértelműen megállapítani. További mintavételezéssel megállapítható lehet, hogy egyszeri szennyezés történt, vagy esetleg folyamatosan fennálló terhelés jelenlétére utalnak a vizsgálati eredmények. 
A 2016-os év során a vas- és mangánkoncentrációt nem határozták meg. A mintavételi helyeken azonban szemmel látható volt a vas- és mangánkicsapódás is. A 2019-es vizsgálati eredmények alapján a felszín alatti vizekre jellemző módon igen magas koncentrációt állapítottunk meg mind a kettő komponens esetében.

\section{Következtetések}

A vizsgálat fő célja az volt, hogy meghatározzuk, a Tiszát alacsony mederteltség esetében tápláló felszín alatti hozzáfolyás jelenthet-e vízminőségi szempontból kockázatot. Ebből a célból regisztrálva lettek a part mentén szemmel látható beáramlások nyomai, illetve ki lettek jelölve egy adott folyószakaszon mintavételi helyek. Fontos megjegyezni azonban, hogy a vízzáró réteg felszínének eltérő domborzata miatt számos szemmel nem látható víz alatti hozzáfolyás is feltételezhető.

A 2019-es év tapasztalatai azt mutatták, hogy a hozzáfolyások számbavételét már az alacsony mederteltség beállta előtt meg kell kezdeni. Ily módon lehetőség van több mintavételi pont kijelölésére is, hogy a folyó nagyobb szakaszán képet kaphasson a szivárgóvizek vízminőségéről.

A szivárgóvizek esetében a legnagyobb problémát az egyes minták magas fémtartalma jelentheti. A 2019-es mintáknál a nikkel és az ólom minden esetben többszöröse volt a megengedettnek. A magas fémterhelés utalhat a közelben található szennyezőforrások jelenlétére.

Hazai sajátosságnak tekinthető a felszín alatti vizek magas arzéntartalma, amely a szigorodó határértékek miatt a későbbiekben jelenthet problémát a felszíni vizek ivóvízcélú felhasználása során is.

A későbbi vizsgálatok során javasolt olyan mintaterületek kijelölése, ahol lehetőség van a talajvíz mintázására egy, a partmenti hozzáfolyás közelében található talajvízkútból. Ily módon jobban összehasonlíthatóvá válnak a különböző rétegek vízminőségei a szivárgóvízzel.

A vizsgált szakaszon gyűjtött és megmért szivárgóvíz mennyisége megközelítőleg 30 l/ óra volt. Ahogyan az előzményekben említettük ez a mérési módszer, illetve eredmény nem alkalmas adott szakaszon a pillanatnyi hozzáfolyás becslésére. Meghatározható azonban adott pontszerű terhelések hozzáfolyása, illetve szennyezőanyag terhelése.

Meglátásunk szerint további vizsgálatokra, az elvárt eredmények meghatározását követően, a meglévő adatbázisok alapján kalibrálható, a valós folyamatokat legalább nagyságrendi szinten leképezni képes modellezési eljárások kidolgozása és alkalmazása során van lehetőség.

\section{Felhasznált irodalom}

Kovács Sándor: Kisköre, déli országhatár közötti Tisza szakasz lefolyásviszonyainak jellemzése. Kézirat. ATIKÖVIZIG - KÖTIKÖVIZIG, 2007. 1-43.

Lászlóffy Woldemár: A Tisza. Budapest, Akadémiai Kiadó, 1982. 
Lehner, Bernhard - Petra Döll - Joseph Alcamo - Thomas Henrichs - Frank Kaspar: Estimating the Impact of Global Change on Flood and Drought Risks in Europe: A Continental, Integrated Analysis. Climatic Change, 75. (2006), 3. 273-299. DOI: https://doi.org/10.1007/s10584-006-6338-4

Nemzeti Vizstratégia. Budapest, Országos Vízügyi Főigazgatóság, 2017. Elérhető: www.vizugy.hu/ vizstrategia/documents/997966DE-9F6F-4624-91C5-3336153778D9/Nemzeti-Vizstrategia.pdf (A letöltés dátuma: 2019. 04. 02.)

Pálfai Imre: Aszályok a Tisza-völgyben. In Fejér László - Kaján Imre (szerk.) Mérlegen a Tisza-szabályozás. Budapest, Magyar Hidrológiai Társaság - Országos Vízügyi Főigazgatóság, 1992. 33-40.

Somlyódy László: Magyarország vízgazdálkodása: helyzetkép és stratégiai feladatok. Budapest, Magyar Tudományos Akadémia, 2011. Elérhető: http://old.mta.hu/data/Strategiai_konyvek/viz/viz_net. pdf (A letöltés dátuma: 2019. 04. 03.)

Szalai Sándor: Drought Tendencies in Hungary and Its Impacts on the Agricultural Production. Cereal Research Communications, 37. (2009), 501-504.

Szlávik Lajos: A Duna és a Tisza szorításában. Budapest, Közdok, 2006.

Szlávik Lajos (szerk.): Vizkárelháritási kézikönyv. Budapest, Országos Vízügyi Föigazgatóság, 2016. Elérhetö: www.ovf.hu/hu/hirek-ovf/vizkarkonyv (A letöltés dátuma: 2019. 04. 10.)

Tamás János: Kihívások az aszálykutatás területén. Hidrológiai Közlöny, 96. (2016), 2. 13-20.

Virágné Kőházi-Kiss Edit - Fejes Lőrinc: A Tisza-tó szerepe az aszály mérséklésében. Budapest, XXXIV. Országos Vándorgyülés konferenciakiadványa, 2016. Elérhető: www.hidrologia.hu/vandorgyules/34/ dolgozatok/word/0329_viragne_kohazi_kiss_edit.pdf (A letöltés dátuma: 2019. 10. 12.)

\section{Jogforrások}

1995. évi LVII. törvény a vízgazdálkodásról

201/2001. (X. 25.) Korm. rendelet az ivóvíz minőségi követelményeiről és az ellenőrzés rendjéről 